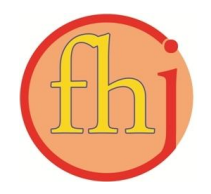

Faletehan Health Journal,5 (3) (2018) 107-116

https://journal.Ippm-stikesfa.ac.id

ISSN 2088-673X| e-ISSN 2597-8667

\title{
Analisis Risiko Keselamatan dan Kesehatan Kerja Pada Petugas Kebersihan di Rumah Sakit
}

\author{
M G Catur Yuantari ${ }^{1 *}$, Hafizhatun Nadia ${ }^{1}$ \\ ${ }^{1}$ Program Studi S1 Kesehatan M asyarakat Fakultas Kesehatan \\ Universitas Dian Nuswantoro Semarang, Indonesia \\ *Corresponding Author: mgcatur.yuantari@ dsn.dinus.ac.id
}

\begin{abstract}
Abstrak
Bekerja di rumah sakit dapat menimbulkan risiko tertular penyakit dari pasien. Risiko ini tidak hanya berpotensi bagi tenaga medis saja, namun juga terhadap tenaga non medis seperti petugas kebersihan. Saat bekerja risiko yang selalu dihadapi oleh petugas kebersihan adalah terpapar faktor biologi dan terpapar bahan kimia atau obat pembersih. Tujuan penelitian ini adalah untuk menganalisis risiko keselamatan dan kesehatan kerja yang dapat terjadi pada petugas kebersihan di RSUD Tugurejo Semarang. Penelitian ini merupakan penelitian deskriptif analitik. Identifikasi risiko menggunakan JSA (Job Safety Analysis), pengambilan data dilakukan dengan cara observasional dan wawancara. Hasil penelitian menunjukkan bahwa risiko yang dihadapi petugas kebersihan adalah risiko terpapar kuman, bakteri dan virus serta terpapar obat kemoterapi, dengan tingkat risiko termasuk dalam high risk (36,6\%). Risiko tertusuk jarum suntik atau tergores benda tajam, terpeleset atau jatuh karena lantai licin, gangguan muskuloskeletal, terjatuh dari tangga, dan tersengat listrik merupakan risiko dengan tingkatan moderate risk (45,1\%). Risiko alergi atau iritasi terhadap penggunaan bahan kimia merupakan risiko dengan tingkatan low risk (18,3\%). Untuk mengendalikan risiko tersebut, disarankan kepada petugas kebersihan agar selalu menggunakan alat pelindung diri yang baik dan benar saat melakukan pekerjaan, menggunakan jenis APD yang sesuai dengan pekerjaan yang dilakukan.
\end{abstract}

Kata Kunci: Analisis risiko, Keselamatan dan Kesehatan Kerja, Petugas Kebersihan

\begin{abstract}
Work at hospital is likely risking get diseases transmission from patients. The risk is not potential to medical staff only, but also nonmedical staff such as cleaning staff. Along doing the work, risk that always faces by cleaning staff are biological factor and chemical such as bleaching. The purpose of the study was to analyze the risk of work health and safety of cleaning staff in Tugurejo hospital Semarang. This study was descriptive analytic study, risk identification assessed with job safety analysis (JSA), data collection had been done with observational and interview. Result showed that the risk faces by cleaning staff was bacteria exposure, bacteria and virus and medical chemotherapy exposure that classified as high risk (36,6\%). The risk of impaled needle and scratched sharp object, slipper, musculoskeletal problem, fall from stairs, and electric shock classified as moderate risk (45,1\%). Allergic risk or irritation through chemical uses classified as low risk (18,3\%). To prevent the risks, suggested to cleaning staff to use personal protection equipment whenever and wherever in doing the job. While, need to evaluate on kind of personal protection equipment that used by cleaning staff especially conformity kind personal protection equipment with the occupation.
\end{abstract}

Keywords: Risk Analysis, Occupational Safety And Health, Janitor 


\section{Pendahuluan}

Keselamatan dan kesehatan kerja merupakan hal penting yang harus diterapkan di semua tempat kerja, baik pada sektor formal maupun sektor informal. Terlebih bagi tempat kerja yang memiliki risiko atau bahaya yang tinggi, serta dapat menimbulkan kecelakaan kerja maupun penyakit akibat kerja. keselamatan dan kesehatan kerja seharusnya diterapkan pada semua pihak yang terlibat dalam proses kerja, mulai dari tingkat manager sampai dengan karyawan biasa. Berdasarkan Undang-Undang No. 1 Tahun 1970 yang menyatakan bahwa setiap tenaga kerja memiliki hak untuk mendapat perlindungan bagi keselamatannya dalam melakukan pekerjaan untuk kesejahteraan hidup dan meningkatkan produksi serta produktivitas Nasional.

Berdasarkan undang-undang No. 44 Tahun 2009 tentang rumah sakit, menyatakan rumah sakit adalah institusi pelayanan kesehatan yang menyelenggarakan pelayanan kesehatan perorangan secara paripurna yang menyediakan pelayanan rawat inap, rawat jalan, dan gawat darurat. Karena merupakan suatu institusi yang bergerak dalam bidang pelayanan kesehatan, maka rumah sakit juga termasuk dalam kategori tempat kerja. Isi dalam pasal 23 undang-undang No. 23 Tahun 1992 tentang kesehatan menyatakan bahwa setiap tempat kerja wajib menyelenggarakan kesehatan kerja. Berdasarkan pernyataan tersebut, maka rumah sakit sebagai salah satu tempat kerja juga wajib untuk menyelenggarakan kesehatan kerja bagi para pekerjanya agar terhindar dari potensi bahaya yang ada di rumah sakit.

Menurut pusat data dan informasi Kementerian Kesehatan RI (2015) tentang situasi kesehatan kerja tahun 2015, Jumlah kasus kecelakaan akibat kerja yang terjadi antara tahun 2011-2014 adalah sebesar 92.453 kasus dengan jumlah kasus paling tinggi terjadi pada tahun 2013 yaitu sebesar 35.917 kasus. Sedangkan data untuk kasus penyakit yang terjadi akibat kerja antara tahun 2011-2014 adalah 57.929 kasus tahun 2011, 60.322 kasus tahun 2012, 97.144 kasus tahun 2013, dan 40.694 kasus pada tahun 2014. Dari data-data tersebut, dapat disimpulkan bahwa situasi kesehatan kerja di Indonesia masih belum baik.

Salah satu tempat kerja yang berisiko adalah Rumah Sakit, hal ini karena rumah sakit memiliki potensi terjadinya penyakit infeksi terhadap para karyawan, pasien, bahkan pengunjung. Beberapa contoh penyakit infeksi yang dapat terjadi di Rumah Sakit adalah TB, Hepatitis B, Hepatitis C, dan bahkan berisiko terinfeksi HIV/AIDS. Selain penyakit-penyakit infeksi, di rumah sakit juga memiliki risiko atau bahaya lain yang mempengaruhi situasi dan kondisi di rumah sakit, seperti kecelakaan (meliputi kejadian ledakan, kebakaran, kecelakaan yang diakibatkan adanya masalah pada instalasi listrik, serta faktor-faktor yang dapat menimbulkan cidera lainnya), radiasi, paparan bahan kimia beracun dan berbahaya, gasgas anastesi, gangguan terkait psikis dan ergonomi. Semua potensi bahaya tersebut di atas, jelas dapat mengganggu dan menimbulkan rasa kurang aman dan nyaman bagi pekerja di RS, pasien maupun pengunjung yang ada di lingkungan RS. (KEPMENKES N0.432 Tahun 2007)

Karyawan rumah sakit terdiri dari tenaga medis dan tenaga non medis. Tenaga medis yaitu dokter, perawat, dan bidan sedangkan tenaga non medis yaitu petugas laundry, petugas kebersihan, petugas penyiapan makanan atau gizi, apoteker, Pemeriksa laboratorium, dan petugas radiologi (Wichaksana, 2002). Dilihat dari jenis pekerjaan yang ada di rumah sakit, dapat dikatakan tenaga medis merupakan karyawan yang rentan terkena penyakit akibat kerja, karena mereka selalu melakukan kontak dengan pasien yang sakit setiap hari. Namun tenaga non medis juga memiliki potensi untuk terkena penyakit akibat kerja, walaupun mereka tidak melakukan kontak langsung dengan pasien. Berbagai penyakit infeksi menular kepada tenaga non medis melalui media udara, lantai, dinding, ruang kerja, jarum suntik bekas, dan infus bekas.

Salah satu tenaga non medis yang ada di rumah sakit adalah petugas kebersihan. Petugas kebersihan adalah karyawan yang bertugas untuk membersihkan lingkungan rumah sakit agar tetap terjaga kebersihannya, karena bahaya yang ada di rumah sakit seperti penularan penyakit dapat terjadi jika lingkungan rumah sakit tidak terjaga kebersihannya. Pekerjaan membersihkan lingkungan rumah sakit, membuat petugas kebersihan menjadi rentan terpapar bahaya yang dapat mengganggu kesehatannya. Menurut penelitian Evryanti (2012) bahaya yang dapat mengancam petugas kebersihan rumah sakit antara lain terpapar debu yang dibersihkan, terpeleset saat 
Faletehan Health Journal,5 (3) (2018) 107-116 https://journal.Ippm-stikesfa.ac.id ISSN 2088-673X| 2597-8667

mengepel lantai, kontak dengan bahan kimia yang digunakan untuk mengepel lantai, terpapar bahaya biologi saat membersihkan laboratorium atau ruangan yang mengandung virus dan bakteri, tertusuk benda tajam seperti jarum suntik saat mengelola limbah tajam, sehingga dapat tertular penyakit seperti hepatitis dan HIV/AIDS.

Selain berpotensi tertular penyakit hepatitis dan HIV/AIDS petugas kebersihan rumah sakit juga berisiko terkena penyakit akibat kerja dermatitis kontak dan gangguan muskuloskeletal. Hasil penelitian terhadap 102 petugas cleaning service di Rumah Sakit Umum Abdul Moeloek menunjukkan 47 petugas cleaning service mengalami dermatitis kontak akibat kerja, hasil uji statistik menunjukkan ada hubungan bermakna antara kejadian dermatitis kontak pada cleaning service dengan penggunaan APD, serta ada hubungan antara masa kerja dan kejadian dermatitis kontak. (Saftarina, dkk., 2015) Hasil penelitian lain yang dilakukan di RSUP Dr.Wahidin Sudirohusodo Makassar dengan responden petugas cleaning service menunjukkan bahwa pada Tahun 2013 sebesar 49,1\% petugas cleaning service mengalami gangguan muskuloskeletal berat dan $50,9 \%$ petugas mengalami gangguan muskuloskeletal ringan. Hasil analisis statistik menunjukkan ada hubungan antara variabel umur, jenis kelamin, masa kerja, dan sikap kerja dengan gangguan muskuloskeletal. (Sultan Bedu, 2012)

Rumah Sakit Umum Daerah Tugurejo Semarang merupakan salah satu rumah sakit tipe B milik pemerintah Kota Semarang. Sebagai institusi yang menyediakan pelayanan kesehatan, terutama untuk orang yang sakit, membuat RSUD Tugurejo Semarang juga memiliki potensi untuk terjadinya penyakit akibat kerja dan kecelakaan akibat kerja pada petugas medis, non medis, pasien, maupun pengunjung rumah sakit . Dari hasil survey awal di Rumah Sakit Umum Tugurejo Semarang pada bulan Februari 2017 didapatkan informasi tentang beberapa kejadian kecelakaan kerja kecil pernah dialami beberapa petugas kebersihan yang di wawancarai, seperti luka pada tangan karena tergores benda-benda tajam saat melakukan pekerjaan membersihkan ruangan, terpeleset, serta adanya keluhan-keluhan seperti sakit pinggang dan pegal-pegal pada tangan dan kaki karena terlalu lama duduk atau berdiri saat bekerja. Tujuan penelitian untuk menganalisis risiko keselamatan dan kesehatan kerja pada petugas kebersihan di RSUD Tugurejo Semarang.

\section{Metode Penelitian}

Penelitian ini merupakan penelitian deskriptif analitik dengan desain studi menggunakan metode penilaian risiko dengan teknik kualitatif berdasarkan AS/NZS 4360: 1999, serta identifikasi risiko menggunakan JSA (Job Safety Analysis). Populasi dari penelitian ini adalah seluruh petugas kebersihan yang bekerja di RSUD Tugurejo Semarang sebanyak 125 petugas kebersihan yang terdiri dari 42 orang petugas di zona A, 44 orang petugas di zona $\mathrm{B}$ dan 39 orang petugas di zona $\mathrm{C}$. Sampel dari penelitian ini adalah sebagian dari jumlah petugas kebersihan yang ada di RSUD Tugurejo Semarang. Penentuan sampel dilakukan dengan metode accidental sampling dimana subyek yang dijadikan responden berdasarkan yang ditemui pada saat melakukan penelitian dan bersedia untuk diwawancarai. Berdasarkan hasil perhitungan dengan menggunakan rumus Slovin didapatkan jumlah sampel sebanyak 55 orang petugas kebersihan yang akan dijadikan responden. Penelitian ini dilakukan dalam beberapa tahapan, antara lain :

1. Melakukan observasi tentang alur pekerjaan yang dilakukan oleh petugas kebersihan serta dilakukan wawancara untuk melengkapi data terkait proses pekerjaan yang dilakukan.

2. Melakukan identifikasi risiko keselamatan dan kesehatan kerja pada setiap tahap atau proses kerja yang dilakukan oleh petugas kebersihan. Identifikasi risiko menggunakan JSA (Job Safety Analysis).

3. Memberikan penilaian terhadap kemungkinan dan konsekuensi yang dapat ditimbulkan pada setiap risiko keselamatan dan kesehatan kerja yang mungkin terjadi pada petugas kebersihan. Proses ini menggunakan tabel penilaian Likelihood (kemungkinan) dan tabel Consequence (Akibat) dari AS/NZS 4360 : 1999.

4. Menganalisis besarnya tingkat risiko keselamatan dan kesehatan kerja yang dapat terjadi pada petugas kebersihan di RSUD Tugurejo Semarang.

5. Merekomendasikan cara pengendalian risiko keselamatan dan kesehatan kerja yang dapat diterapkan pada petugas kebersihan di RSUD Tugurejo Semarang, baik dengan cara 
eliminasi, substitusi, pengendalian teknis, pengendalian administratif, maupun penggunaan alat pelindung diri (APD).

\section{Hasil dan Pembahasan}

Petugas kebersihan yang ada di RSUD Tugurejo Semarang bukan berasal dari rumah sakit itu sendiri, tetapi berasal dari dua perusahaan jasa berbeda yang menyediakan tenaga kerja untuk melakukan kegiatan pembersihan atau yang sering disebut sebagai cleaning service. Alur pekerjaan yang dilakukan oleh petugas kebersihan yang ada di RSUD Tugurejo Semarang adalah sebagai berikut:

1. Membuang sampah yang ada di sekitar ruangan atau lingkungan tempat mereka bekerja, baik sampah medis maupun sampah non medis. Sampah-sampah tersebut diambil dari kotak sampah yang telah tersedia dan telah dipisahkan antara tempat sampah medis dan tempat sampah non medis. Sampahsampah tersebut dimasukkan didalam kantong plastik besar khusus untuk mengangkut sampah, selanjutnya akan di buang ke TPS yang ada di RSUD Tugurejo Semarang.

2. Membersihkan perabotan yang ada di semua ruangan yang ada di wilayah petugas kebersihan tersebut ditugaskan. Yaitu membersihkan perabotan seperti meja, kursi, melap kaca jendela, pintu, less steinless, alatalat yang ada di ruang kantor, ruang dokter, ruang perawat, IGD, ruang pasien, laboratorium, laundry, bagian gizi dan lainlain.

3. Menyapu lantai ruangan dan selasar yang ada di rumah sakit. Untuk menyapu lantai biasanya petugas menggunakan obi atau sering disebut mengobi.

4. Mengepel lantai ruangan dan selasar yang ada di rumah sakit. Untuk mengepel lantai petugas kebersihan menggunakan bahan-bahan kimia seperti disenfektan yang berguna untuk membersihkan sekaligus membunuh kumankuman yang ada di lantai.

5. Membersihkan toilet dan kamar mandi. Setelah menyelesaikan pekerjaan yang lain petugas kebersihan akan membersihkan kamar mandi yang ada di rumah sakit, baik kamar mandi untuk umum, pasien, dokter, perawat, maupun karyawan kantor. Membersihkan kamar mandi dimulai dengan menyikat lantai, membersihkan closet, dinding kamar mandi, wastafel, dan kaca yang ada di kamar mandi sampai bersih. Untuk membersihkan kamar mandi juga menggunakan beberapa bahan kimia atau Larutan pembersih.

6. General cleaning adalah pekerjaan yang dilakukan oleh petugas kebersihan di luar dari tugas pokok atau rutinitas yang harus dilakukan setiap harinya. Pekerjaan yang dilakukan pada saat general cleaning adalah membersihkan kamar pasien yang kosong atau pasien yang baru saja pulang dari rumah sakit, membersihkan sawang atau kotoran yang ada di langit-langit ruangan, membersihkan dinding ruangan, membersihkan lift dan masih banyak lagi program lainnya yang ada dalam general cleaning.

7. Membersihkan halaman dan taman yang berada di lingkungan rumah sakit. Pekerjaan yang dilakukan mulai dari menyapu halaman, membersihkan rumput-rumput liar di taman, merawat tanaman, dan berkebun atau menanam tanaman di taman-taman yang ada di lingkungan rumah sakit.

Untuk menghindari atau mengurangi risiko, petugas kebersihan di RSUD Tugurejo diwajibkan untuk menggunakan alat pelindung diri setiap kali melakukan pekerjaan. Alat pelindung diri yang wajib digunakan adalah masker, sarung tangan latek, dan sepatu boot ketika bekerja di daerah yang licin atau tempat tertentu lainnya. Alat pelindung diri tersebut tidak disediakan oleh pihak rumah sakit, tetapi disediakan oleh perusahaan jasa tempat petugas kebersihan ini bekerja. Namun terkadang masih ada petugas yang tidak menggunakan alat pelindung diri yang lengkap saat bekerja, seperti tidak menggunakan masker atau sarung tangan.

Petugas kebersihan yang bekerja di RS Tugurejo terbagi atas 3 Zona yaitu Zona A berjumlah 42 , Zona B ada 44 dan zona $\mathrm{C}$ ada 39 orang petugas, sehingga jenis pekerja atau peran itu masing-masing petugas berbeda tergantung Zonanya. Berikut ini hasil identifikasi bahaya dengan job safety analysis, Job Safety Analysis (JSA) terfokus pada mengidentifikasi bahaya dan cara mengontrol bahaya tersebut agar tidak terjadi saat anda bekerja. Sedangkan Standard Operating Prosedure (SOP) cenderung dengan bagaimana 
Faletehan Health Journal,5 (3) (2018) 107-116 https://journal.Ippm-stikesfa.ac.id ISSN 2088-673X| 2597-8667

langkah melaksanakan pekerjaan agar pekerjaan tersebut dilakukan dengan cara yang benar dan aman.

Dari hasil identifikasi risiko kemudian dilakukan penilaian terhadap kemungkinan terjadi dan konsekuensi dari tiap risiko untuk di analisis tingkat risikonya didapatkan hasil $36,6 \%$ risiko berada pada tingkatan high risk yaitu risiko terpapar debu dan kuman, terpapar bakteri atau pun virus dan terpapar obat kemoterapi, 45,1\% risiko pada tingkatan moderate risk yaitu risiko tertusuk jarum suntik, tergores benda tajam, terpeleset atau terjatuh karena lantai licin dan gangguan muskuloskeletal, $18,3 \%$ risiko pada tingkatan low risk yaitu risiko alergi atau iritasi terhadap penggunaan bahan kimia seperti pembersih lantai dan lainnya.

Disamping hasil identifikasi dan analisis risiko dilakukan juga wawancara terhadap 55 Pekerja kebersihan, didapatkan data kecelakaan dan keluhan kesehatan yang pernah dialami.

Kecelakaan kerja ini dapat terjadi karena tindakan tidak aman yang dilakukan oleh petugas kebersihan, seperti tidak menggunakan APD saat membersihkan kaca atau pintu. Namun juga dapat terjadi karena alat pelindung diri yang digunakan tidak safety, seperti menggunakan sarung tangan yang mudah sobek ketika terkena benda tajam. Sarung tangan yang digunakan petugas kebersihan adalah sarung tangan latek, sarung tangan ini dianggap masih kurang safety untuk mencegah risiko untuk tergores benda tajam. Jika saat membersihkan kaca petugas kebersihan. mengayunkan tangannya terlalu kencang dan bergoresan dengan kaca atau steinless maka memungkinkan untuk sarung tangan tersebut mengalami sobekan kecil yang juga akan menimbulkan luka gores pada jari tangan petugas kebersihan.

Setiap pekerja pasti pernah mengalami keluhan selama bekerja baik itu keluhan pikiran, kesehatan, dan lainnya. Petugas kebersihan di RSUD Tugurejo memiliki beberapa keluhan terkait kesehatannya seperti pegal-pegal, pusing, gangguan pernafasan, gangguan tulang/sendi, alergi terhadap bahan kimia yang digunakan dan keluhan lainnya. Sebesar 27\% petugas kebersihan mengalami keluhan pegal-pegal hal ini dapat disebabkan karena gerakan yang mereka lakukan saat bekerja berulang-ulang. Sebesar $16 \%$ petugas yang pernah mengalami pusing ini dapat disebabkan karena kebanyakan dari petugas kebersihan belum makan atau sarapan pagi ketika memulai pekerjaan, sehingga tubuh menjadi lemah dan menimbulkan rasa pusing. Petugas yang mengalami gangguan pernafasan terjadi ketika membersihkan debu dalam ruangan, petugas kebersihan yang mengalami gangguan tulang atau sendi adalah petugas kebersihan yang berusia diatas 50 tahun, ini dapat disebabkan karena faktor penuaan yang menyebabkan turunnya fungsi tulang dan sendi. Sedangkan yang mengalami alergi bahan kimia adalah petugas yang memiliki kulit sensitif sehingga sering merasa gatal ketika menggunakan bahan kimia atau obat pembersih.

Grafik 1. Jenis Kecelakaan/luka yang pernah dialami oleh Pekerja Kebersihan

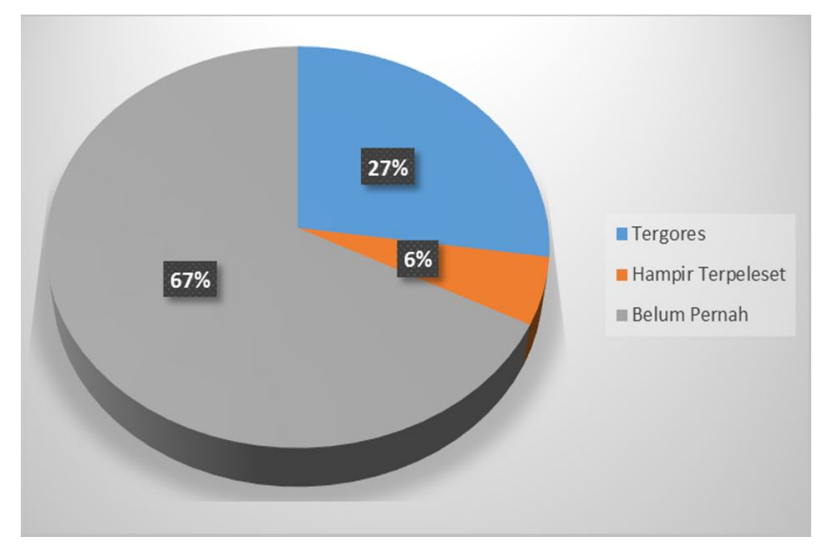

Grafik 2. Keluhan Kesehatan yang Pernah dialami oleh Pekerja

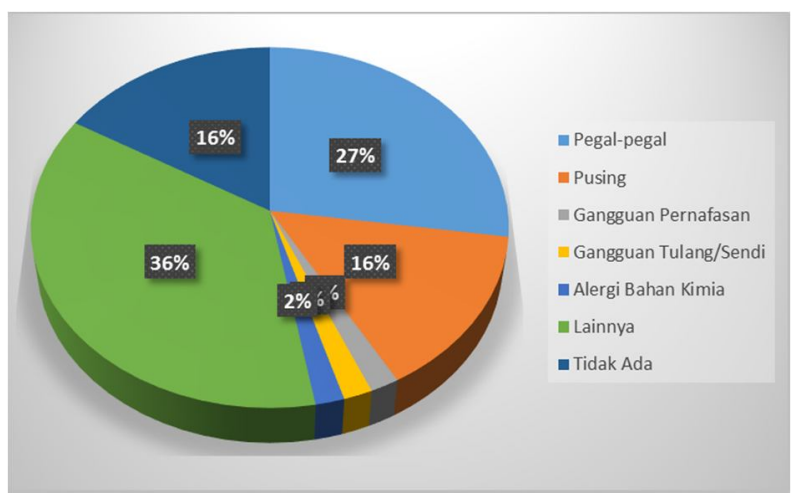


Tabel 1. Identifikasi Potensi Bahaya Pada Pekerja Kebersihan di RSUD Tugurejo

\begin{tabular}{|c|c|c|c|c|c|c|c|c|c|c|}
\hline \multirow[t]{2}{*}{ No } & \multirow{2}{*}{$\begin{array}{c}\text { Rincian } \\
\text { Pekerjaan }\end{array}$} & \multirow[t]{2}{*}{ Risiko } & \multirow{2}{*}{$\begin{array}{l}\text { Likeli } \\
\text { hood }\end{array}$} & \multicolumn{5}{|c|}{$\begin{array}{c}\text { Risk Matrik } \\
\text { (consequence) }\end{array}$} & \multirow[t]{2}{*}{ Hasil Wawancara } & \multirow[t]{2}{*}{ Pengendalian } \\
\hline & & & & 1 & 2 & 3 & 4 & 5 & & \\
\hline \multirow[t]{2}{*}{1} & $\begin{array}{l}\text { Memasukkan } \\
\text { sampah } \\
\text { kedalam } \\
\text { plastik }\end{array}$ & $\begin{array}{l}\text { Terpapar kuman/ } \\
\text { bakteri }\end{array}$ & $\mathrm{A}$ & $\mathbf{H}$ & $\mathrm{H}$ & $\mathrm{E}$ & $\mathrm{E}$ & $\mathrm{E}$ & $\begin{array}{l}98,2 \% \text { responden } \\
\text { menyatakan risiko } \\
\text { bekerja dirumah } \\
\text { sakit terpapar/ } \\
\text { Bakteri/ Kuman } \\
\text { (menyebabkan } \\
\text { terinfeksi Penyakit) }\end{array}$ & $\begin{array}{l}\text { Menggunakan } \\
\text { Masker, Sarung } \\
\text { Tangan, dan } \\
\text { Selalu mencuci } \\
\text { tangan sebelum } \\
\text { dan sesudah } \\
\text { bekerja. }\end{array}$ \\
\hline & & $\begin{array}{l}\text { Tertusuk atau } \\
\text { tergores benda atau } \\
\text { sampah tajam } \\
\text { (kaca, aluminium } \\
\text { dll) }\end{array}$ & $\mathrm{C}$ & $\mathrm{L}$ & $\mathbf{M}$ & $\mathrm{H}$ & $\mathrm{E}$ & $\mathrm{E}$ & $\begin{array}{l}27,3 \% \text { petugas } \\
\text { kebersihan pernah } \\
\text { mengalami luka } \\
\text { gores saat bekerja }\end{array}$ & $\begin{array}{l}\text { Menggunakan } \\
\text { sarung tangan }\end{array}$ \\
\hline 2 & $\begin{array}{l}\text { Mengelap kaca } \\
\text { jendela, pintu, } \\
\text { dan less } \\
\text { steinless pada } \\
\text { jendela kaca } \\
\text { dan pintu. }\end{array}$ & $\begin{array}{l}\text { Tergores kaca atau } \\
\text { less steinless }\end{array}$ & $\mathrm{C}$ & $\mathrm{L}$ & $\mathbf{M}$ & $\mathrm{H}$ & $\mathrm{E}$ & $\mathrm{E}$ & $\begin{array}{l}27,3 \% \text { petugas } \\
\text { kebersihan pernah } \\
\text { mengalami luka } \\
\text { gores saat bekerja }\end{array}$ & $\begin{array}{l}\text { Menggunakan } \\
\text { sarung tangan }\end{array}$ \\
\hline 3 & $\begin{array}{l}\text { Menyapu } \\
\text { lantai \& } \\
\text { ruangan kantor }\end{array}$ & $\begin{array}{l}\text { Terpapar debu dan } \\
\text { kuman yang ada di } \\
\text { ruangan kantor }\end{array}$ & $\mathrm{A}$ & $\mathrm{H}$ & $\mathbf{H}$ & $\mathrm{E}$ & $\mathrm{E}$ & $\mathrm{E}$ & $\begin{array}{l}98,2 \% \text { responden } \\
\text { menyatakan risiko } \\
\text { bekerja dirumah } \\
\text { sakit terpapar/ } \\
\text { Bakteri/ Kuman }\end{array}$ & $\begin{array}{l}\text { Menggunakan } \\
\text { Masker, Sarung } \\
\text { Tangan, dan } \\
\text { Selalu mencuci } \\
\text { tangan sebelum } \\
\text { dan sesudah } \\
\text { bekerja. }\end{array}$ \\
\hline \multirow[t]{4}{*}{4} & $\begin{array}{l}\text { Membersihkan } \\
\text { kamar mandi } \\
\text { di Ruang } \\
\text { Rawat Inap }\end{array}$ & $\begin{array}{l}\text { Terpeleset dan jatuh } \\
\text { karna lantai kamar } \\
\text { mandi yang licin. }\end{array}$ & $\mathrm{E}$ & $\mathrm{L}$ & $\mathrm{L}$ & $\mathbf{M}$ & $\mathrm{H}$ & $\mathrm{H}$ & $\begin{array}{l}3,6 \% \text { petugas } \\
\text { menyatakan pernah } \\
\text { mengalami hampir } \\
\text { terpeleset }\end{array}$ & $\begin{array}{l}\text { Menggunakan } \\
\text { sepatu boot }\end{array}$ \\
\hline & & $\begin{array}{l}\text { Terpapar kuman, } \\
\text { bakteri atau virus } \\
\text { dari pasien yang } \\
\text { menggunakan } \\
\text { kamar mandi }\end{array}$ & A & $\mathbf{H}$ & $\mathrm{H}$ & $\mathrm{E}$ & $\mathrm{E}$ & $\mathrm{E}$ & $\begin{array}{l}98,2 \% \text { responden } \\
\text { menyatakan risiko } \\
\text { bekerja dirumah } \\
\text { sakit } \\
\text { terpapar/Bakteri/Ku } \\
\text { man }\end{array}$ & $\begin{array}{l}\text { Menggunakan } \\
\text { masker, sarung } \\
\text { tangan, dan } \\
\text { selalu mencuci } \\
\text { tangan sebelum } \\
\text { dan sesudah } \\
\text { bekerja }\end{array}$ \\
\hline & & $\begin{array}{l}\text { Alergi atau iritasi } \\
\text { kulit karena kontak } \\
\text { dengan bahan kimia } \\
\text { atau obat pembersih } \\
\text { kamar mandi }\end{array}$ & $\mathrm{E}$ & $\mathrm{L}$ & $\mathbf{L}$ & M & $\mathrm{H}$ & $\mathrm{H}$ & $\begin{array}{l}1,8 \% \text { petugas } \\
\text { menyatakan } \\
\text { mengalami alergi } \\
\text { terhadap bahan } \\
\text { kimia }\end{array}$ & $\begin{array}{l}\text { Menggunakan } \\
\text { sarung tangan }\end{array}$ \\
\hline & & $\begin{array}{l}\text { Gangguan } \\
\text { Muskuloskeletal/ } \\
\text { nyeri pinggang } \\
\text { karna sering } \\
\text { menbungkuk. }\end{array}$ & $\mathrm{C}$ & $\mathrm{L}$ & $\mathbf{M}$ & $\mathrm{H}$ & $\mathrm{E}$ & $\mathrm{E}$ & $\begin{array}{l}27,3 \% \text { petugas } \\
\text { mengalami } \\
\text { gangguan } \\
\text { muskuloskeletar } \\
\text { seperti pegal, sakit } \\
\text { pinggang }\end{array}$ & $\begin{array}{l}\text { Bekerja pada } \\
\text { posisi yang } \\
\text { aman dan } \\
\text { nyaman }\end{array}$ \\
\hline
\end{tabular}


Faletehan Health Journal,5 (3) (2018) 107-116

https://journal.Ippm-stikesfa.ac.id

ISSN 2088-673X| 2597-8667

\begin{tabular}{|c|c|c|c|c|c|c|c|c|}
\hline \multirow[t]{2}{*}{ No } & \multirow{2}{*}{$\begin{array}{c}\text { Rincian } \\
\text { Pekerjaan }\end{array}$} & \multirow[t]{2}{*}{ Risiko } & \multirow{2}{*}{$\begin{array}{c}\text { Likeli } \\
\text { hood }\end{array}$} & \multicolumn{3}{|c|}{$\begin{array}{c}\text { Risk Matrik } \\
\text { (consequence) }\end{array}$} & \multirow[t]{2}{*}{ Hasil Wawancara } & \multirow[t]{2}{*}{ Pengendalian } \\
\hline & & & & 1 & 23 & 45 & & \\
\hline 5 & $\begin{array}{l}\text { Membersihkan } \\
\text { tumpahan } \\
\text { darah di ruang } \\
\text { HD (Jika } \\
\text { Terjadi saja) }\end{array}$ & $\begin{array}{l}\text { Terpapar kuman, } \\
\text { bakteri, atau virus } \\
\text { yang ada pada } \\
\text { tumpahan darah } \\
\text { pasien }\end{array}$ & $\mathrm{E}$ & $\mathbf{L}$ & L $\quad \mathrm{M}$ & $\mathrm{H}$ & $\begin{array}{l}\text { 98,2\% responden } \\
\text { menyatakan risiko } \\
\text { bekerja dirumah } \\
\text { sakit terpapar/ } \\
\text { Bakteri/ Kuman } \\
\text { (menyebabkan } \\
\text { terinfeksi Penyakit) }\end{array}$ & $\begin{array}{l}\text { Menggunakan } \\
\text { masker, sarung } \\
\text { tangan, cuci } \\
\text { tangan sebelum } \\
\text { dan sesudah } \\
\text { bekerja }\end{array}$ \\
\hline 6 & $\begin{array}{l}\text { Mengepel } \\
\text { lantai ruangan }\end{array}$ & $\begin{array}{l}\text { Terpeleset atau } \\
\text { jatuh karena lantai } \\
\text { licin. }\end{array}$ & $\mathrm{E}$ & $\mathrm{L}$ & L $\quad \mathbf{M}$ & $\mathrm{H}$ & $\begin{array}{l}3,6 \% \text { petugas } \\
\text { menyatakan pernah } \\
\text { mengalami hampir } \\
\text { terpeleset }\end{array}$ & $\begin{array}{l}\text { Menggunakan } \\
\text { alas kaki yang } \\
\text { tidak licin dan } \\
\text { mengepel lantai } \\
\text { sampai kering } \\
\end{array}$ \\
\hline 7 & $\begin{array}{l}\text { Membersihkan } \\
\text { rumput liar } \\
\text { yang ada di } \\
\text { taman rumah } \\
\text { sakit }\end{array}$ & $\begin{array}{l}\text { Tergores cangkul } \\
\text { kecil atau benda } \\
\text { tajam lain yang } \\
\text { digunakan untuk } \\
\text { membersihkan } \\
\text { rumput. }\end{array}$ & $\mathrm{D}$ & $\mathrm{L}$ & L $\quad$ M & $\mathrm{H}$ & $\begin{array}{l}27,3 \% \text { petugas } \\
\text { kebersihan pernah } \\
\text { mengalami luka } \\
\text { gores saat bekerja }\end{array}$ & $\begin{array}{l}\text { Menggunakan } \\
\text { sarung tangan, } \\
\text { bekerja dengan } \\
\text { hati-hati }\end{array}$ \\
\hline 8 & $\begin{array}{l}\text { Membersihkan } \\
\text { lift }\end{array}$ & $\begin{array}{l}\text { Terpapar debu, } \\
\text { bakteri, kuman, } \\
\text { atau virus yang } \\
\text { menempel pada } \\
\text { dinding lift }\end{array}$ & $\mathrm{A}$ & $\mathbf{H}$ & $\mathrm{H} \quad \mathrm{E}$ & $\mathrm{E}$ & $\begin{array}{l}\text { 98,2\% responden } \\
\text { menyatakan risiko } \\
\text { bekerja dirumah } \\
\text { sakit terpapar/ } \\
\text { Bakteri/Kuman } \\
\text { (menyebabkan } \\
\text { terinfeksi Penyakit) }\end{array}$ & $\begin{array}{l}\text { Menggunakan } \\
\text { masker, sarung } \\
\text { tangan, cuci } \\
\text { tangan sebelum } \\
\text { dan sesudah } \\
\text { bekerja }\end{array}$ \\
\hline
\end{tabular}

*) Warna Hitam bold merupakan penilaian risiko

Catatan:

Likelihood : A (Almost Certain), B (Likely), C (Possible), D (Unlikely), E (rare)

Consequensy : 1 (Insignificant), 2 (Minor), 3 (Moderate), 4 (Major), 5 (catastrophic)

Tingkat Resiko : E (Extreme Risk), H (High Risk), M (Moderate Risk), L (Low Risk)

Setiap tempat tentunya memiliki risiko dan bahaya masing-masing sesuai dengan karakteristik tempat kerja tersebut. Contohnya penelitian yang dilakukan pada sebuah perusahaan manufaktur, risiko yang terdapat di perusahaan tersebut meliputi kebakaran, luka/memar/terpeleset, gangguan pernafasan, kesetrum, gangguan pada mata, dehidrasi dan gangguan pada pendengaran.(Yuliawati, 2012) Risiko yang berbeda terdapat pada pekerja yang bekerja pada proyek pembangunan ruko, yaitu terjatuh, kejatuhan/tertimpa benda yang jatuh, tersengat listrik, terkena bahan-bahan yang berbahaya atau radiasi, serta juga ada risiko terjadinya kebakaran. (Alfons, 2013) Perbedaan risiko ini dapat terjadi karena perbedaan kondisi lingkungan tempat kerja, alat dan bahan yang digunakan dan juga proses kerja yang dilakukan. Pekerjaan sebagai seorang petugas kebersihan juga memiliki risiko bagi keselamatan dan kesehatan pekerjanya, walaupun mungkin jika dilihat risiko atau bahaya tersebut dianggap bukan masalah besar. Petugas kebersihan yang bekerja di sebuah perusahaan atau kantor akan memiliki risiko yang berbeda dengan petugas kebersihan yang bekerja di sebuah rumah sakit.

Hasil identifikasi risiko K3 pada petugas kebersihan di RSUD Tugurejo Semarang adalah terpapar debu, kuman, bakteri dan virus, tertusuk jarum suntik dan tergores kaca atau benda tajam, terpeleset atau terjatuh karena lantai licin, alergi dengan bahan kimia, gangguan muskuloskeletal, terpapar obat kemoterapi, terjatuh dari tangga, tersengat listrik dan terpapar bahan kimia atau pupuk tanaman. Penelitian dengan metode identifikasi risko dilakukan pada instalasi laundry rumah sakit, hasil penelitian tersebut menyatakan risiko yang dapat terjadi pada petugas laundry adalah tersengat listrik, kebakaran, terinfeksi 
bakteri, terhirup bahan kimia, kaki terinjak troli, terpeleset dan terjatuh akibat lantai licin, terjepit pintu, tersandung dan kejatuhan ember saat menimbang linen. (Bilad, 2013) Hal ini menunjukkan bahwa risiko yang paling identik di rumah sakit adalah terpapar bakteri, kuman dan virus. Hal ini karena, rumah sakit merupakan tempat untuk orang sakit yang ingin berobat. Persamaan risiko yang lain adalah terpeleset karena lantai licin dan terpapar bahan kimia, ini dikarenakan petugas kebersihan dan petugas laundry sama-sama bekerja dibidang pembersihan. Sehingga mereka lebih banyak bekerja dengan menggunakan air yang dapat menimbulkan risiko terpeleset karena lantai licin, dan juga menggunakan bahan atau cairan pembersih yang mengakibatkan mereka sering terpapar bahan kimia.

Untuk dapat bekerja secara aman dan nyaman, sangat dibutuhkan prosedur kerja. Prosedur kerja adalah petunjuk atau langkah-langkah kerja yang telah disusun sedemikian rupa sebagai panduan bagi tenaga kerja dalam melakukan pekerjaan. Prosedur kerja disusun dengan tujuan agar para pekerja dapat melakukan pekerjaan dengan baik dan benar, agar dapat menghasilkan pekerjaan yang baik pula, serta terhindar dari berbagai bahaya atau risiko yang dapat terjadi di lingkungan kerja. Petugas kebersihan telah memiliki prosedur kerja yang dibuat dan disosialisasikan oleh perusahaan jasa tempat mereka bekerja. Mereka diwajibkan untuk mengikuti setiap langkah yang ada diprosedur kerja secara berurutan. Dari hasil wawancara 98,2\% responden menjawab bahwa mereka selalu melakukan pekerjaan sesuai dengan prosedur yang ada, mereka beranggapan bahwa dengan mengikuti prosedur akan menghasilkan pekerjaan yang baik, aman, dan maksimal. Sedangkan satu orang petugas kebersihan menjawab terkadang bekerja tidak sesuai dengan urutan yang ada. Petugas tersebut beranggapan bahwa melakukan pekerjaan dengan tahapan mana saja yang didahulukan akan menghasilkan hasil kerja yang sama dan aman-aman saja.

Berdasarkan hasil wawancara sebesar $83,6 \%$ petugas kebersihan menjawab pernah mengikuti pelatihan tentang $\mathrm{K} 3$, pelatihan tersebut diselenggarakan oleh perusahaan jasa tempat petugas kebersihan bekerja. $16,4 \%$ petugas kebersihan menjawab belum pernah mengikuti pelatihan tentang K3. Petugas kebersihan yang belum mengikuti pelatihan adalah petugas yang memiliki masa kerja kurang dari satu tahun yaitu masih dalam hitungan beberapa bulan saja. Mereka belum mengikuti pelatihan dikarenakan pelatihan biasanya diselenggarakan setiap 6 bulan sekali sehingga petugas kebersihan yang baru bekerja masih belum bisa mengikuti pelatihan.

Pelatihan K3 sangat penting bagi pekerja terutama bagi pekerja yang tidak mempunyai dasar pengetahuan tentang K3 dan bekerja di lingkungan kerja dengan risiko atau bahaya yang tinggi. Pelatihan ini bertujuan untuk memberikan pengetahuan tentang K3, yang nantinya akan dapat diterapkan oleh petugas kebersihan di tempat kerja, sehingga mereka dapat lebih berhati-hati dalam bekerja. Menurut Murti, (2010) Sebuah penelitian hubungan antara pelatihan keselamatan dan kesehatan kerja dengan perilaku aman pada pekerja konstruksi menyatakan bahwa terdapat korelasi positif dan hubungan yang signifikan antara skor pelatihan K3 dengan perilaku aman pada pekerja konstruksi. Jadi petugas kebersihan yang sudah mengikuti pelatihan K3 akan memiliki kecenderungan untuk mengubah perilaku mereka menjadi lebih aman saat bekerja.

Untuk mencegah terjadinya kecelakaan atau penyakit akibat kerja adalah melakukan pengendalian terhadap risiko tersebut. Pengendalian yang sudah dilakukan oleh pihak perusahaan adalah menyediakan alat pelindung diri berupa masker, sarung tangan, dan sepatu boot. Penggunaan APD memang sering di pilih sebagai pengendalian bahaya untuk mengurangi atau mencegah terjadinya kecelakaan kerja ataupun penyakit akibat kerja. Hasil penelitian tentang pengaruh pemakaian APD terhadap kejadian kecelakaan kerja menunjukkan bahwa kepatuhan atau selalu menggunakan APD dapat membuat angka kejadian kecelakaan kerja semakin rendah. (Anggraini, 2011) Selain itu perusahaan juga melakukan pelatihan tentang housekeeping maupun K3 bagi petugas kebersihan.

Pihak rumah sakit telah memberikan himbauan atau pemberitahuan untuk tetap menjaga kebersihan kesehatan diri saat bekerja, seperti mencuci tangan sebelum dan sesudah bekerja. Tindakan mencuci tangan sebelum dan sesudah bekerja sangatlah penting bagi pekerja yang bekerja di rumah sakit hal ini dapat menurunkan kejadian infeksi atau penularan penyakit. Hasil penelitian tentang hubungan pelaksanaan tindakan 
Faletehan Health Journal,5 (3) (2018) 107-116 https://journal.Ippm-stikesfa.ac.id ISSN 2088-673X| 2597-8667

cuci tangan perawat dengan kejadian infeksi di rumah sakit menyatakan bahwa terdapat hubungan yang bermakna antara pelaksanaan cuci tangan dengan kejadian infeksi. (Alfred. 2010) Selain itu rumah sakit juga mengadakan pelatihan pada pekerjanya termasuk petugas kebersihan boleh mengikuti pelatihan yang biasa dilakukan rumah sakit adalah pelatihan APAR dan tentang bantuan hidup dasar.

Pengendalian yang dilakukan untuk mencegah atau mengendalikan risiko yang ada sebenarnya sudah cukup baik dengan menyediakan alat pelindung diri, membekali pekerjanya dengan pelatihan, dan memberikan himbauan atau peringatan untuk selalu menjaga kebersihan dan kesehatan diri. Namun masih terjadinya kecelakaan kecil seperti tergores kaca atau steinless pada petugas kebersihan dapat diakibatkan karena kurang berhati-hati dalam bekerja dapat juga terjadi karena jenis alat pelindung yang kurang pas untuk pekerjaan tersebut. Oleh karena itu perlu dilakukan peningkatan kesadaran diri pada petugas kebersihan dalam menjaga keselamatan dan kesehatan saat bekerja. Hal itu dapat dilakukan dengan cara:

1. Pemberian reward bagi pekerja yang selalu bekerja dengan baik dan mentaati peraturan yang ada serta memberikan punishment berupa teguran kepada pekerja yang tidak mematuhi peraturan saat bekerja. Diharapkan dengan adanya hal seperti itu dapat meningkatkan kesadaran petugas kebersihan, dan dapat meningkatkan produktivitasnya dalam bekerja.

2. Selain itu juga dapat dilakukan evaluasi mengenai penyediaan alat pelindung diri. Yaitu melakukan evaluasi mengenai jenis alat pelindung diri yang cocok untuk setiap kegiatan yang dilakukan petugas kebersihan misalnya sarung tangan yang digunakan saat membersihkan kaca atau pintu yang dibingkai steinless sebaiknya menggunakan sarung tangan yang berbahan tebal dan tidak mudah sobek (bukan sarung tangan latek). Karena sebelumnya belum pernah dilakukan evaluasi terkait alat pelindung diri yang tepat untuk setiap kegiatan kerja yang dilakukan oleh petugas kebersihan.

\section{Simpulan}

Petugas Kebersihan di RS mempunyai risiko saat bekerja antara lain terpapar debu, kuman, bakteri dan virus, tertusuk atau tergores benda tajam, Alergi dengan bahan kimia, gangguan muskuloskeletal seperti pegal-pegal, sakit pinggang atau punggung, terpapar obat kemoterapi, terjatuh dari tangga, tersengat listrik, dan terpapar bahan kimia dalam bentuk pupuk. Berdasarkan tingkat resiko diketahui bahwa 18,3\% risiko berada pada tingkatan low risk, $45,1 \%$ risiko pada tingkatan moderate risk dan 36,6\% risiko pada tingkatan high risk

\section{Referensi}

Alfons, Bryan, 2013. Manajemen Risiko Keselamatan dan Kesehatan Kerja (K3) Pada Proyek Pembangunan Ruko Orlens Fashion Manado Jurnal Sipil Statistik. Vol. 1. 23376732.

Alvadri, Zilpianus, 2016. Hubungan Pelaksanaan Tindakan Cuci Tangan Perawat dengan Kejadian Infeksi Rumah Sakit di Rumah Sakit Sumber Waras Grogol. Jakarta.

Anggraini, Rulik Tri, 2011. Pengaruh Pemakaian APD terhadap Kejadian Kecelakaan Kerja pada Perajin Batu Marmer di Desa Gamping Kabupaten Tulungagung. Tulungagung.

Bilad, Anisa Imadul, 2012. Analisis Risiko Keselamatan dan Kesehatan Kerja pada Instalasi Laundry RSUD Kota Semarang. Semarang.

Evryanti, 2012. Kajian Risiko Keselamatan dan Kesehatan Kerja Pada Petugas Kesehatan dan Petugas Kebersihan Klinik X. Universitas Indonesia Jakarta.

KEPMENKES N0.432 Tahun 2007. Tentang Pedoman Manajemen Kesehatan dan Keselamatan Kerja di Rumah Sakit. Jakarta Indonesia.

Murti, Andrea Krisna, 2010. Analisis Hubungan Antara Pelatihan Keselamatan dan Kesehatan Kerja dengan Perilaku Aman pada Pekerja Konstruksi Yogyakarta.

Saftarina Fitria, Hendra Tarigan Sibero, Muhammad Aditya, Bela Riski Dinanti, 2015. Prevalensi Dermatitis Kontak Akibat Kerja dan Faktor yang Mempengaruhinya Pada Pekerja Cleaning Service di Rumah Sakit Umum Abdul Moeloek. Lampung. Prosiding Seminar Presentasi Artikel Ilmiah Dies 
Natalis FK Unila ke-13. Diakses di http://fk.unila.ac.id/wp-content/uploads/ 2016/06/4.pdf

Semarang, RSUD Tugurejo. Profil RSUD Tugurejo Semarang . RSUD Tugurejo Provinsi Jawa Tengah. [Online] [Dikutip: Senin Maret 2017.] http://www.rstugurejo.com/beranda/.

Sultan Bedu, Hajrah Hi, Syamsiar S. Russeng, Muhammad Rum Rahim Sultan Bedu, 2013. Faktor yang Berhubungan dengan Gangguan Muskuloskeletal Pada Cleaning Service di RSUP DR.Wahidin Sudirohusodo Makasar. Makasar. Diakses https://core.ac.uk/ download/pdf/25491576. pdf
Undang-Undang No.1 Tahun 1970. Tentang Keselamatan Kerja. Jakarta Indonesia.

Undang-Undang No.23 Tahun 1992. Tentang Kesehatan . Jakarta Indonesia.

Undang-Undang No.44 Tahun 2009. Tentang Rumah Sakit. Jakarta Indonesia.

Wichaksana, Aryawan, 2002. Penyakit Akibat Kerja di Rumah Sakit dan Pencegahannya. Cermin Dunia Kedokteran. 0125-913X.

Yuliawati, Evi, 2012. Analisis Risiko Keselamatan dan Kesehatan Kerja Pada Proses Produksi PT.Abadi Adimulia. 